\title{
Cogeneration of renewable energy from biomass (utilization of municipal solid waste as electricity production: gasification method)
}

\author{
Misgina Tilahun · Omprakash Sahu • \\ Manohar Kotha $\cdot$ Hemlata Sahu
}

Received: 14 October 2014 / Accepted: 24 January 2015 / Published online: 13 February 2015

(C) The Author(s) 2015. This article is published with open access at Springerlink.com

\begin{abstract}
Recycling and utilization of waste is one of the key parameters of environmental issue. For this issue supercritical waste gasification has impactive impression, which has capability to convert the waste into marketable by-product. Adding catalysts or oxidants to supercritical waste gasifier can further reduce operating costs by creating self-sustaining reactions under mild conditions with even shorter residence times. The hydrogen produced by this process will be utilized for generating electricity using fuel cell technology. Besides, alkaline fuel cells appear to be an important technology in the future as they can operate at a high efficiency. Therefore, the combination of biomass gasification through supercritical water with alkaline fuel cells represents one of the most potential applications for highly efficient utilization of biomass. The main aim of the study is to recover energy from waste using alkaline fuel cell. With the different operation conditions $88.8 \%$ of hydrogen and $45 \%$ of carbon dioxide, maximum power density $9.24 \mathrm{~W} / \mathrm{cm}^{2}$ was obtained.
\end{abstract}

Keywords Biomass $\cdot$ Cell $\cdot$ Energy $\cdot$ Hydrogen $\cdot$ Reactor

\section{Introduction}

Biomass is one of the renewable and potentially sustainable energy sources and has many possible applications varying

M. Tilahun · O. Sahu ( $\square)$

Department of Chemical Engineering, Wollo University, South

Wollo, Ethiopia

e-mail: ops0121@gmail.com

M. Kotha $\cdot$ H. Sahu

Department of Electrical and Electronic Engineering, Wollo University, South Wollo, Ethiopia from heat generation to the production of advanced secondary energy carriers. It has almost zero or very low net $\mathrm{CO}_{2}$ emission since carbon and energy are fixed during the biomass growth [1]. There are different types of technologies for converting biomass to electricity or to a secondary fuel such as thermal conversion, chemical conversion and bio-chemical conversion [2]. However, thermo-chemical methods such as gasification have a great potential in producing a syngas mainly composed of $\mathrm{H}_{2}$ and $\mathrm{CO}$ with traces of different gases such as $\mathrm{CH}_{4}$ in different proportions [3]. The produced fuel gas can be flexibly utilized in boilers, engines, gas turbines or fuel cells [4]. Smaller scale gasification systems with internal combustion engines can now be used for thousands of hours to give reasonably high electrical efficiencies and limited emissions [5]. However, fuel cells have the potential to operate at higher electrical efficiency and with lower emissions compared with traditional power generation techniques. Fuel cells are emerging as a leading alternative technology to the more polluting internal combustion engines in vehicle and stationary distributed energy applications. In addition, the future demand for portable electric power supplies is likely to exceed the capability of current battery technology. Hydrogen-powered fuel cells emit only water and have virtually no pollutant emissions, even nitrogen oxides, because they operate at temperatures that are much lower than internal combustion engines [6]. However, even fuel cells fuelled by hydro- carbon fuels have the potential to provide efficient, clean and quiet energy conversion, which can contribute to a significant reduction in greenhouse gases and local pollution. When heat generated in fuel cells is also utilized in combined heat and power (CHP) systems, an overall efficiency of $85 \%$ in excess can be achieved [7]. Different types of fuel cells suitable for several energy applications at varying scales 
have been developed, but all share the basic design of two electrodes (anode and cathode) separated by a solid or liquid electrolyte or a membrane. Hydrogen (or a hydrogen-containing fuel) and air are fed into the anode and cathode of the fuel cell, and the electrochemical reactions assisted by catalysts take place at the electrodes [8]. The electrolyte enables transport of ions between the electrodes while the excess electrons flow through an external circuit to provide electrical power. Fuel cells are classified according to the nature of their electrolyte, which also determines their operating temperature, the type of fuel and a range of applications [9]. The electrolyte can be acid, base, salt or a solid ceramic or polymeric membrane that conducts ions.

Gasification is a process that converts organic or fossil based carbonaceous materials into carbon monoxide, hydrogen and carbon dioxide. Hydrogen and fuel cells are often considered as a key technology for future sustainable energy supply. Renewable shares of $36 \%$ (2025) and $69 \%$ (2050) on the total energy demand will lead to hydrogen shares of $11 \%$ in 2025 and $34 \%$ in 2050 [10]. Today, hydrogen is mainly produced from natural gas via steam methane reforming, and although this process can sustain an initial foray into the hydrogen economy, it represents only a modest reduction in vehicle emissions as compared to emissions from current hybrid vehicles [11]. Biomass has been recognized as a major world renewable energy source to supplement declining fossil fuel resources $[12,13]$. It will play an important role in the future global energy infrastructure for the generation of power and heat, but also for the production of chemicals and fuels. The dominant biomass conversion technology will be gasification, as the gases from biomass gasification are intermediates in the high-efficient power production or the synthesis from chemicals and fuels. Biomass gasification offers the earliest and most economical route for the production of renewable hydrogen. International Institute for Applied Systems Analysis (IIASA's) Environmentally Compatible Energy Strategies (ECS) project has developed a long-term hydrogen-based scenario (B1-H2) of the global energy system to examine the future perspectives of fuel cells [14].

The scenario illustrates the key role of hydrogen in a long-term transition towards a clean and sustainable energy future. According to this scenario, biomass gasification will become a dominant technology in the future. The main aim of the work is to utilize the sewage sludge for the production of hydrogen and uses it for electricity generation. This work concentrated on the percentage of hydrogen production with variation of temperature, pressure and residence time by gasification method. Effect of partial pressure of produced hydrogen, working temperature and electrolyte concentration on cell performance has also been studied.

\section{Materials and methods}

\section{Material}

The material was arranged from solid waste dumping area of Kombolcha town (Ethiopia).

\section{Reactor set up}

The reactor vessel was dual-shell type with an insert made of titanium, widely utilized as corrosion-resistant metal, and a pressure shell. The reactor used in this study was also equipped with auxiliaries such as a stirrer, thermocouples, nozzles, and a pressure gauge. The reaction was initiated by immersing the reactor into molten salt bath (mass ratio of salt was adjusted to $\mathrm{K}_{2} \mathrm{NO}_{3}: \mathrm{NaNO}_{2}: \mathrm{NaNO}_{3}=6: 5: 1$ ). After lapse of predefined time, the reactor was taken out of the bath and subsequently quenched to stop the reaction. HPLC high-pressure pump was used for feeding the distilled water to the reactor to adjust the reaction pressure precisely. The reaction temperature was measured by K-type thermocouple and pressure with digital pressure gauge. The reactor was loaded with deionized water and initial sewage sludge ( $2 \mathrm{wt} \%$ of deionized water) for every experiment $(250 \mathrm{rpm}$ and particles size $180 \mu \mathrm{m})$. The amount of catalyst was $20 \mathrm{wt} \%$ of the organic waste. Then, the air in the reactor was replaced with argon gas. The reactor was sealed and put into the sand bath heated at reaction temperature. It took about $3 \mathrm{~min}$ for the reactor to reach the setting reaction temperature around $700{ }^{\circ} \mathrm{C}$. It took about $2 \mathrm{~min}$ for final setting of the reaction pressure and reaction time will be considered as zero. As the reaction pressure increased by about $1 \mathrm{MPa}$ than the initial reaction pressure for all experiments, the reaction pressure was assumed to be the initial reaction pressure of the experiment.

\section{Gas analysis}

Produced gas was sampled from one of the sampling loop ports using a gas-tight syringe for gas analysis injection. Liquid and solid residues were collected as mixtures subsequently separated by centrifugation run at 2,500 rpm for $5 \mathrm{~min}$. Moreover, the liquid phase was filtered by $0.45 \mu \mathrm{m}$ pore size syringe filter (Millex LH, Millipore) and diluted by deionized water prior to the analysis. Separated solid (small amount) residues were dried in an oven kept at $105{ }^{\circ} \mathrm{C}$ for at least $6 \mathrm{~h}$ and weighed. Gas analysis was carried out with gas chromatograph (GC) GC-2014; SHMADZU equipped with Shin-carbon ST 50/80 column and thermal conductivity detector (TCD) to separate $\mathrm{H}_{2}$, $\mathrm{CH}_{4}, \mathrm{CO}$, and $\mathrm{CO}_{2}$. As for the ICP analysis of initial sewage sludge, acid decomposition by nitric acid and 
sulfuric acid was conducted under $210^{\circ} \mathrm{C}$ using an electric hot plate [15]. Guaranteed grade of potassium hydroxide provided by Wako Pure Chemicals Industries, Ltd. was used as a catalyst for gasification.

Preparations of electrode

The anode electrode was prepared by first dispersing the required quantity of catalyst powder in a Nafion ${ }^{\circledR}$ dispersion (SE-5112) for $30 \mathrm{~min}$. An ultrasonic water bath was used to prepare catalyst slurry. The Nafion ${ }^{\circledR}$ dispersions have both hydrophilic and hydrophobic features. Polytetrafluoroethylene (PTFE) is hydrophobic and when employed as a binder, it may prevent hydrophilic fuel from reaching the catalyst site. Therefore, Nafion ${ }^{\circledR}$ has been used to bind the catalyst particles on to the carbon paper. The catalyst slurry was spread on carbon paper in the form of a continuous wet film using a paint-brush technique. It was then dried in an oven for $30 \mathrm{~min}$ at $80{ }^{\circ} \mathrm{C}$. Nickel meshes were used as a current-collector because of its non-corrosive nature in an alkaline medium. The catalyzed carbon paper was pressed on to the nickel mesh with application of the Teflon ${ }^{\circledR}$ dispersion. The prepared electrode was pressed at $50 \mathrm{~kg} \mathrm{~cm}{ }^{-2}$ and $120{ }^{\circ} \mathrm{C}$ for $5 \mathrm{~min}$ to form a composite structure. The area of the working electrode was $25 \mathrm{~cm}^{2}$. Finally, the composite was heated at $573 \mathrm{~K}$ for $4 \mathrm{~h}$ to obtain the final form of the anode electrode [16]. Similarly, we have used magnesium oxide for cathode electrode. The Teflon-coated side of the electrode was exposed to the airside in alkaline fuel cell, and thereby prevented leakage of electrolyte to the air-side and allowed oxygen to permeate.

\section{Experimental setup}

The experiments were carried out in a $7 \mathrm{~cm} \times 7 \mathrm{~cm}$ stainless steel plate in which a special new designed electrolyte carrier plate is fitted with bolts. The cathode $(5 \mathrm{~cm} \times 5 \mathrm{~cm})$ and anode $(5 \mathrm{~cm} \times 5 \mathrm{~cm})$ are placed in front and back side of electrolyte carrier. A wire connected with the anode and the cathode is used as terminals for measuring current and voltage of the alkaline fuel cell. The space between the anode and the cathode was filled with electrolyte $(\mathrm{KOH})$ with the help of peristaltic pump. The electrolyte was feeded $1 \mathrm{ml} \mathrm{min}^{-1}$, such that one side of the cathode was in contact with the electrolyte and the other side was exposed to air. Oxygen present in the air acts as an oxidant. The hydrogen gas which was generated from the biomass by gasification method is used as anode feed and oxygen is taken from the air. The electrolyte in the beaker was continuously stirred by a magnetic stirrer to maintain a uniform concentration and temperature in the beaker and to reduce any concentration polarization near the electrodes. The voltage and current were measured after a steady state is reached. The complete experimental setup for the production of hydrogen (reactor) and supply for electricity generation (fuel cell) is shown in Fig. 1.

\section{Results and discussion}

Effect of temperature, pressure and residence time

Temperature, pressure, and residence time have been noted to be the most important variables for modifying supercritical reaction conditions [17]. Optimal supercritical conditions can be experimentally derived and aided by models to induce the ideal combination of temperature, pressure, and residence time [18]. System optimization, however, involves maximizing the desired output (energy or organic destruction), while reducing reaction times to minutes or seconds versus the hours required for similar results in subcritical water [19]. The effect of temperature, pressure and residence time is shown in Fig. $2 \mathrm{a}-\mathrm{c}$.

\section{Effect of temperature}

At the chemical equilibrium state, the yields of $\mathrm{H}_{2}$ and $\mathrm{CO}_{2}$ increase with the increasing temperature, but the yield of $\mathrm{CH}_{4}$ decreases sharply. The equilibrium $\mathrm{CO}$ yield is very small, and it is about $10^{-3} \mathrm{~mol} / \mathrm{kg}$. As temperature increases from 400 to $800{ }^{\circ} \mathrm{C}$, the $\mathrm{CO}$ yield firstly increases and then drops down. The maximum $\mathrm{CO}$ yield is reached at about $550{ }^{\circ} \mathrm{C}$. Hydrogen yield increases at a low speed at rather higher temperature. When the reaction temperature is above $650{ }^{\circ} \mathrm{C}$, biomass gasification goes to completion and the equilibrium gas product consists of $\mathrm{H}_{2}$ and $\mathrm{CO}_{2}$ in a molar ratio equal to $(2-y+x / 2)(x$ and $y$ are the elemental molar ratios of $\mathrm{H} / \mathrm{C}$ and $\mathrm{O} / \mathrm{C}$ in biomass, respectively). The maximal equilibrium $\mathrm{H}_{2}$ yield $88.623 \% \mathrm{~mol} / \mathrm{kg}$ of wet biomass was obtained, which is shown in Fig. 2a. From the viewpoint of thermodynamics, higher temperature is essential for hydrogen production. Temperature is considered the most sensitive variable in SCWG processes, with $600{ }^{\circ} \mathrm{C}$ serving as an often-cited, optimal target temperature due to associated high conversion [20-22].

\section{Effect of residence time}

At the chemical equilibrium state, the yields of $\mathrm{H}_{2}$ and $\mathrm{CO}_{2}$ increase with the increasing residence time, but the yield of $\mathrm{CH}_{4}$ and $\mathrm{CO}$ decreases sharply, which is shown in Fig. 2 b. Initially $\mathrm{H}_{2}$ and $\mathrm{CO}_{2}$ were 49 and $23 \%$ of the yield which is slow; and after 30 min they gradually increased and at $60 \mathrm{~min}$, they reached up to 88.8 and $50 \%$. But in the case of $\mathrm{CH}_{4}$ and $\mathrm{CO}$ it decreased from 27 and $16 \%$ to $10^{-3} \mathrm{~mol} / \mathrm{kg}$. Longer residence time can improve 


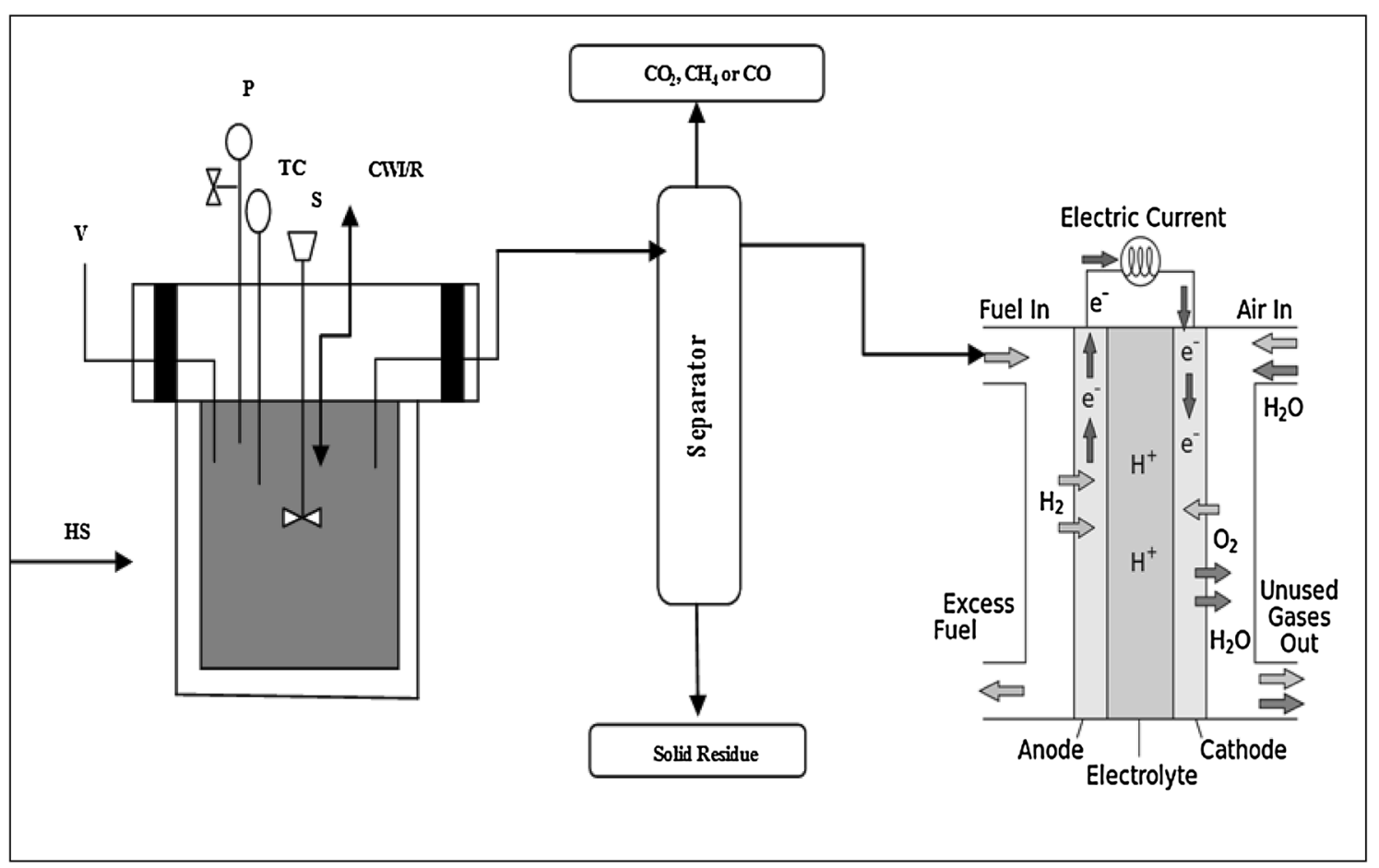

HS: Heat supply, V: Valve, P: Pressure gauge, TC: Thermocouple, S: Stirrer, CWI/R: Cooling water inlet and return

Fig. 1 Schematic diagram of experimental setup. $H S$ Heat supply, $V$ Valve, $P$ Pressure gauge, $T C$ Thermocouple, $S$ Stirrer, $C W I / R$ Cooling water inlet and return

gasification thoroughness, but there is also an inverse relationship between temperature and reaction completeness, dropping from a few minutes below $600{ }^{\circ} \mathrm{C}$ to a few seconds above $600{ }^{\circ} \mathrm{C}$. The optimal temperature threshold for SCWG (i.e., $600{ }^{\circ} \mathrm{C}$ ) has been shown on the lower side of the conversion range for higher concentration biomass in the absence of a catalyst [23-26]. From the viewpoint of thermodynamics, biomass can be gasified completely in SCW with a product formation of $\mathrm{H}_{2}$ and $\mathrm{CO}_{2}$, but adequate reaction time was required to complete the gasification process. Short residence times and high organics destruction efficiencies occur during gasification and oxidative reactions at supercritical operating conditions above $600{ }^{\circ} \mathrm{C}[27]$.

\section{Effect of pressure}

The effect of pressure on equilibrium gas yields at $600{ }^{\circ} \mathrm{C}$ at 30 min using different pressure. At $25 \mathrm{MPa}$ the $\mathrm{H}_{2}$ and $\mathrm{CO}_{2}$ were 75 and $40 \%$ of yeilds, with increase in pressure; little changes were found, which are shown in Fig. 2c. Pressure shows a complex effect on biomass gasification in SCW. The properties of water, such as density, static dielectric constant and ion product increase with pressure. As a result, the ion reaction rate increases and free-radical reaction is restrained with an increase of pressure.
Hydrolysis reaction plays a significant role in SCWG of biomass, which requires the presence of $\mathrm{H}^{+}$or $\mathrm{OH}^{-}$. With increasing pressure, the ion product increases, therefore the hydrolysis rate also increase. Besides, high pressure favors water-gas shift reaction, but reduces decomposition reaction rate. But in the case of $\mathrm{CH}_{4}$ and $\mathrm{CO}$ it was very less or negiable but with the increase in the pressure it increased slowly. The complex pressure effects can be used to fine tune the chemical composition of the solvent and control gas composition with yield [28]. Specifically, pressure has little or no influence on reaction rate, but it does affect solvent density. Density also has little effect on gasification efficiency above the critical point, but can have significant affects on gas fraction characteristics [29]. High pressures, and correspondingly higher densities, favor $\mathrm{CH}_{4}$ production and inhibit $\mathrm{H}_{2}$ production.

Effect of partial pressure of hydrogen in cell performance pressure

To investigate the effect of hydrogen partial pressure on the cell performance, the cell performance is studied with different hydrogen partial pressures of $0.5,0.8,1$ and $1.2 \mathrm{~atm}$, respectively. The partial pressure is adjusted by mixing argon. The cell performance with different partial pressures of hydrogen at a temperature of $65^{\circ} \mathrm{C}$ is shown 

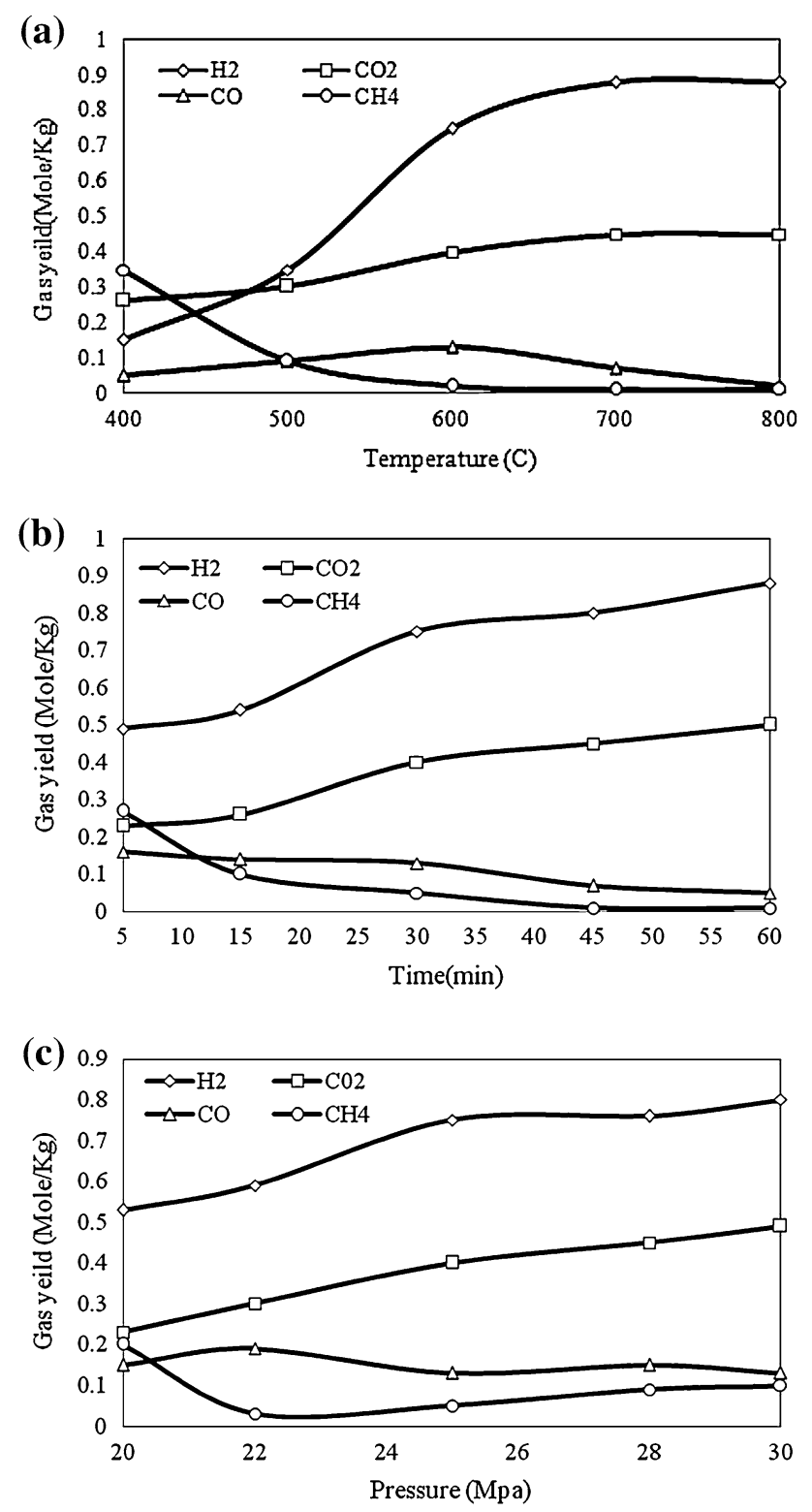

Fig. 2 a Gas yeild using different temperature at fixed $25 \mathrm{MPa}$ pressure and time $30 \mathrm{~min}, \mathbf{b}$ Gas yeild using differnet retension time at fixed $600{ }^{\circ} \mathrm{C}$ temperature and $25 \mathrm{Mpa}$ pressure, c Gas yield using different pressure at fixed $600{ }^{\circ} \mathrm{Ctemperature} \mathrm{and} \mathrm{time} 30 \mathrm{~min}$

in Fig. 3. The power density rises with the increase of the hydrogen partial pressure. The increase in cell open circuit voltage will be somewhat less because of the greater gas solubility at increasing pressure which produces higher lost currents. When the partial pressure of hydrogen is higher than $0.8 \mathrm{~atm}$, the cell can keep a high output performance as that of cell using pure hydrogen. The maximum power density of $9.24 \mathrm{~W} / \mathrm{cm}^{2}$ was obtained using pure hydrogen. The maximum power density only decreased by about $13 \%$ when the partial pressure of hydrogen decreased from
$1 \mathrm{~atm}$ to 0.8 and $1.2 \mathrm{~atm}$. However, the cell performance decreases dramatically as the partial pressure of hydrogen decreases to $0.5 \mathrm{~atm}$. The maximum power density is only $6.5 \mathrm{~W} / \mathrm{cm}^{2}$ at a partial pressure of hydrogen of $0.2 \mathrm{~atm}$.

The OCV can be calculated from the Nernst equation:

$$
E=E^{\mathrm{O}}+(R T / 2 F) \ln \left(P_{\mathrm{H}_{2}} / P_{\mathrm{H}_{2} \mathrm{O}}\right)+(R T / 2 F) \ln \left(P_{\mathrm{O}_{2}}^{1 / 2}\right)
$$

where $E^{\mathrm{o}}$ is the open circuit voltage (OCV) at standard pressure. $F$ is the Faraday constant and $R$ is the gas constant. $T$ is the absolute temperature. $P_{\mathrm{O}_{2}}$ is the partial pressure at the cathode. And $P_{\mathrm{H}_{2}}$ and $P_{\mathrm{H}_{2} \mathrm{O}}$ are the partial pressures of hydrogen and vapour at the anode. It can be found that the OCV is dependent on cell temperature, hydrogen and water concentration in the fuel gas (anode) and oxygen in the cathode.

The above equation can be changed to:

$E=E^{\mathrm{o}}+\frac{R T}{2 F} \ln \left(\frac{P_{\mathrm{O}_{2}}^{1 / 2}}{P_{\mathrm{H}_{2} \mathrm{O}}}\right)+\frac{R T}{2 F} \ln \left(P_{\mathrm{H}_{2}}\right)$

If the hydrogen pressure changes from $P_{1}$ to $P_{2}$ and the partial pressures of $P_{\mathrm{H}_{2} \mathrm{O}}$ and $P_{\mathrm{O}_{2}}$ keep constant, there will be a change of voltage at $65^{\circ} \mathrm{C}$ :

$$
\begin{aligned}
\Delta V & =\frac{R T}{2 F} \ln \left(P_{2}\right)-\frac{R T}{2 F} \ln \left(P_{1}\right)=\frac{R T}{2 F} \ln \left(\frac{P_{2}}{P_{1}}\right) \\
& =0.053 \ln \left(\frac{P_{2}}{P_{1}}\right) V
\end{aligned}
$$

These experimental data are in good agreement with the difference of reversible cell voltage calculated based on Nernst equation.

\section{Effect of temperature in cell performance}

In the cell, reaction process becomes faster when the electrolyte is warm rather than cold. So, the temperature plays an important role to develop the voltage across terminal. Figure 4 shows the current-voltage relationship for using different temperature at $1 \mathrm{~atm}$ and $2 \mathrm{M}$ of electrolyte solution was fed to the alkaline fuel cell. It is seen that the cell performance increases with the increase in temperature because of decrease in the activation and concentration over-potentials [30]. In addition, mass transport limitations are reduced at higher temperatures. The overall result is an improvement in cell performance or in other words the conductivity of $\mathrm{KOH}$ solutions is relatively high at low temperatures. For instance an alkaline fuel cell designed to operate at $75{ }^{\circ} \mathrm{C}$ will reduce to only half power level when its operating temperature is reduced to room temperature. The maximum power density $9.36,9.24,6.6$, and $6.12 \mathrm{~W} /$ $\mathrm{cm}^{2}$ was obtained when temperature is $75,65,55$, and 
Fig. 3 Cell performance at different partial pressure at $65{ }^{\circ} \mathrm{C}$ and 2 mol electrolyte concentration
Fig. 4 Cell performance using different temperature at $1 \mathrm{~atm}$. Pressure and 2 mol electrolyte concentration
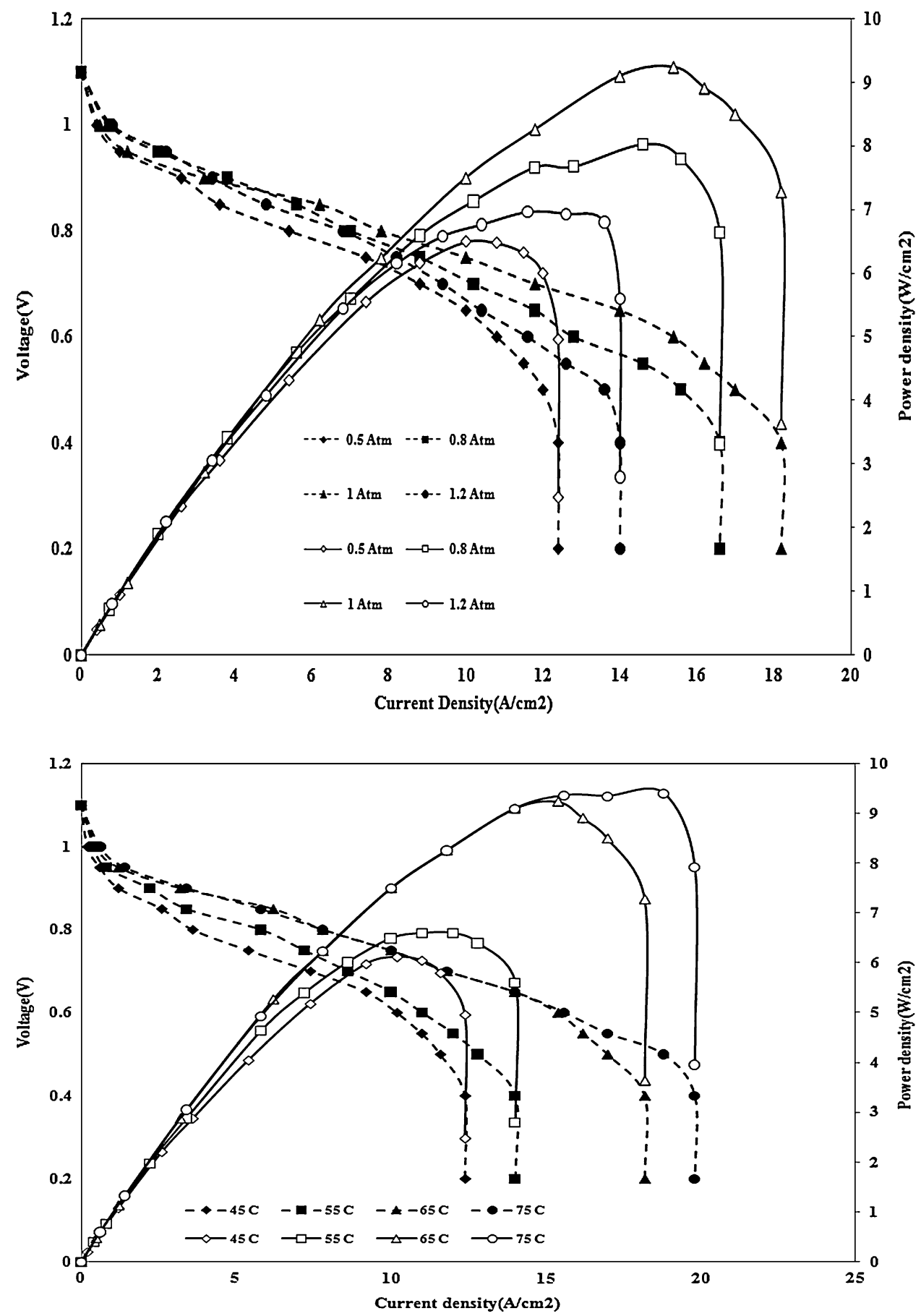

$45^{\circ} \mathrm{C}$. This result was found similar to author, who used methanol and ethanol fuel at 25,45 and $65^{\circ} \mathrm{C}$. The performance increases with the increase in temperature because of decrease in activation over potential concentration and mobility at higher temperature [31].

\section{Effect of electrolyte concentration in cell performance}

A higher current flow (amperage) through the cell means it will be passing more electrons through it at any given time. This means a faster rate of reduction at the cathode and a faster rate of oxidation at the anode. This corresponds to a greater number of moles of the product. The amount of current that passes depends on the concentration of the electrolyte; it shows different value in different concentration of electrolyte used. Figure 5 shows that the cell voltage increases with the increase in $\mathrm{KOH}$ concentration from 1 to $2 \mathrm{M}$ for a particular load and then it decreases with further increase in $\mathrm{KOH}$ concentration. It is well known that the initial and final voltage losses with 
Fig. 5 Cell performance using different fuel concentration at $65{ }^{\circ} \mathrm{C}$ temperature and $1 \mathrm{~atm}$ pressure

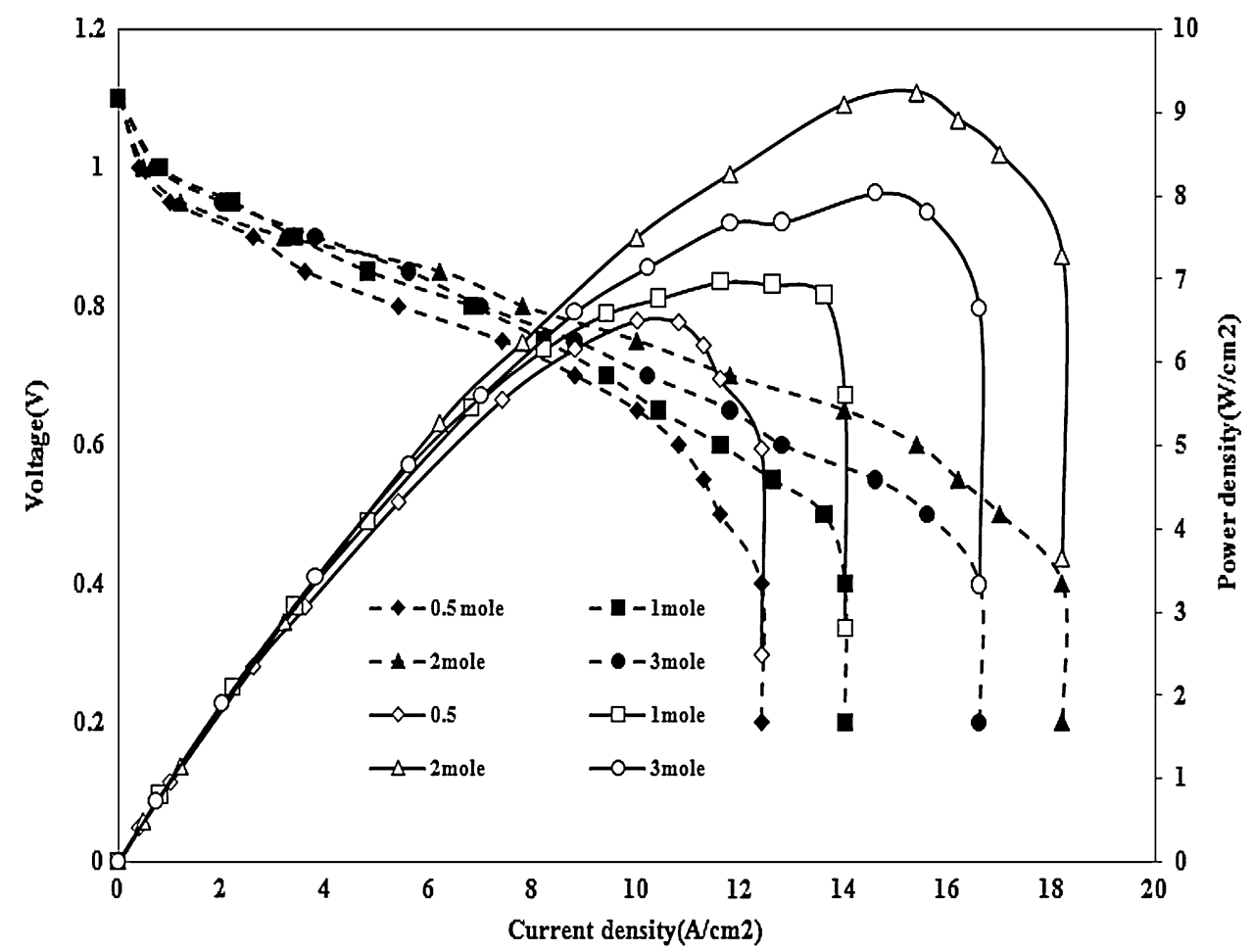

an increase in current consumption and are attributed to activation and concentration over-potentials, whereas the over-potential in the flattened portion of the curve is due to ohmic loss [32]. It is apparent from Fig. 5 that the increase in $\mathrm{KOH}$ concentration has minimum effect on activation over-potential while the concentration overpotential first decreases and then increases with the increase in $\mathrm{KOH}$ concentration. The concentration polarization increases at a higher $\mathrm{KOH}$ concentration because of less availability of hydrogen at the anode. On the other hand, the lowering of the $\mathrm{KOH}$ concentration increases the ionic conductivity of the medium or decreases the ohmic loss. The cell performance is maximum at $2 \mathrm{M}$ of electrolyte concentration obtained at $9.24 \mathrm{~W} / \mathrm{cm}^{2}$, and lowest at $0.5 \mathrm{M}$ was $6.48 \mathrm{~W} / \mathrm{cm}^{2}$. While further increase in electrolyte beyond $2 \mathrm{M}$, it was found the cell performance decreases.

\section{Conclusion}

It concludes that the contents of hydrogen and carbon dioxide vary with different operation conditions and obtained $88.8 \%$ of hydrogen and approximate $45 \%$ of carbon dioxide at temperature $\left(600^{\circ} \mathrm{C}\right)$, pressure $(25 \mathrm{MPa})$, and residence time $(60 \mathrm{~min})$. Although supercritical water gasification of wet biomass seems promising for the production of hydrogen rich gas, it should be noticed that a high concentration of biomass is necessary to reach commercial goals. From the experiment we find the maximum power density $9.24 \mathrm{~W} / \mathrm{cm}^{2}$ was obtained at $75{ }^{\circ} \mathrm{C}(\mathrm{Tem}-$ perature) $2 \mathrm{M}$ (Electrolyte concentration) and $1 \mathrm{~atm}$ (Pressure). The development of hydrogen and fuel-cell technologies is set to play a central role in addressing growing concerns over carbon emissions and climate change as well as the future availability and security of energy supply. Hydrogen can be generated from biomass, but this technology urgently needs further development. It is believed that in the future, biomass can become an important sustainable source of hydrogen. Due to its environmental merits, the share of hydrogen from biomass in the automotive fuel market will grow fast in the next decade. Gasification of biomass has been identified as a possible system for producing renewable hydrogen, which is beneficial to exploit biomass resources, to develop a highly efficient clean way for large-scale hydrogen production, and has less dependence on insecure fossil energy sources. Steam reforming of natural gas and gasification of biomass will become the dominant technologies by the end of the 21 st century.

Open Access This article is distributed under the terms of the Creative Commons Attribution License which permits any use, distribution, and reproduction in any medium, provided the original author(s) and the source are credited. 


\section{References}

1. Dincer, I.: Technical, environmental and exergetic aspects of hydrogen energy systems. Int. J. Hydrog. Energy. 27, 265-285 (2007)

2. Arena, U.: Process and technological aspects of municipal solid waste gasification. A review. Waste. Manag. 32, 625-639 (2012)

3. Baratieri, M., Baggio, P., Fiori, L., Grigiante, M.: Biomass as an energy source: thermodynamic constraints on the performance of the conversion process. Biotechnol. 99, 7063-7073 (2008)

4. Franco, A., Giannini, N.: Perspectives for the use of biomass as fuel in combined cycle power plants. Int. J. Therm. Sci. 44, 163-168 (2005)

5. Anon, C.: Reducing greenhouse gas emissions and electrical power costs. Biocycle. 45(10), 35-36 (2004)

6. Appleby, A.J., Foulkes, F.R.: Fuel cell handbook. Van Nostrand Reinhold, New York (1993)

7. Dutton, AG.: Hydrogen energy technology. Tyndall Working Paper TWP17, Tyndall Centre for Climate Change. http://www. tyndall.ac.uk/publications/working_ papers/wp17.pdf (2008). Accessed 15 May 2008

8. Crabtree, G.W., Dresselhaus, M.S., Buchanan, M.V.: The hydrogen economy. Phy. Today. 57, 39-44 (2004)

9. Novochinskii, I., Ma, X., Song, C., Lambert, J., Shore, L., Farrauto, R.: A ZnO-based sulfur trap for $\mathrm{H}_{2} \mathrm{~S}$ removal from reformate of hydrocarbons for fuel cell applications. Proceedings of Topical Conference on Fuel Cell Technology. AIChE Spring National Meeting, New Orleans, vol. 11-14, pp. 98-105. (2002)

10. Turner, J.A.: Sustainable hydrogen production. Inform. 305, 971-974 (2004)

11. Unal, H., Alibas, K.: Agricultural residues as biomass energy. Energy. Sources. Part. B. 2, 123-140 (2007)

12. Boerrigter, H., Rauch, R.: Review of applications of gases from biomass gasification. In: Knoef, HAM. (ed.) Proceedings of the handbook biomass gasification. The Netherlands: Biomass Technology Group (BTG). pp. 211-230 (2005)

13. Barreto, L., Makihira, A., Riahi, K.: Medium and long-term demand and supply prospects for fuel cells: the hydrogen economy and perspectives for the 21st century. International Institute for Applied Systems Analysis, Laxenburg (2002)

14. Sealock, L.J.J., Elliott, D.C., Baker, E.G., Fassbender, A.G., Silva, L.J.: Hydrogen production by supercritical water gasification. Ind. Eng. Chem. Res. 35, 4111-4120 (1996)

15. Clean Renewable Fuel from the Plasma Gasification of Waste, http://www.waste-management-world.com (2011). Accessed 16 May 2011

16. Elliott, D.C., Hart, T.R., Neuenschwander, G.G.: Chemical processing in high pressure aqueous environments: improved catalysts for hydrothermal gasification. Ind. Eng. Chem. Res. 45(11), 3776-3781 (2006)
17. Soria, J.A., McDonald, A.G., Shook, S.R.: Wood solubilization and depolymerization using supercritical methanol. Part 1: process optimization and analysis of methanol insoluble components (Bio-Char). Holzforschung 14(4), 402-408 (2008)

18. Gloyna, E.F., Li, L.: Supercritical water oxidation: an engineering update. Waste. Manag. 14, 379-394 (1993)

19. D’Jesus, P., Boukis, N., Kraushaar-Czarnetzki, B., Dinjus, E.: Gasification of cornand clover grass in supercritical water. Fuel 85, 1032-1038 (2006)

20. Elliott, D.C.: Catalytic hydrothermal gasification of biomass. Bioprod. Biorefining. 2(3), 254-265 (2008)

21. Susanti, R.F., Veriansyah, B., Kim, J.D., Kim, J., Lee, Y.W.: Continuous supercritical water gasification of isooctane: a promising reactor design. Int. J. Hydrog. Energy. 35:51957-1970 (2010)

22. Cao, C., Guo, L., Chen, Y., Guo, S., Lu, Y.: Hydrogen production from supercritical water gasification of alkaline wheat straw pulping black liquor in continuous flow system. Int. J. Hydrog. Energy. 36(21), 13528-13535 (2011)

23. Antal, M.J., Allen, S.G., Schulman, D., Xu, X., Divilio, R.J.: Biomass gasification in supercritical water. Ind. Eng. Chem. Res. 39(11), 4040-4053 (2000)

24. Xu, L., Brilman, D.W.F., Withag, J.A.M., Brem, G., Kersten, S.: Assessment of a dry and a wet route for the production of biofuels from microalgae: energy balance analysis. Bioresour. Technol. 102(8), 5113-5122 (2011)

25. Xu, X., Matsumura, Y., Stenberg, J., Antal, M.J.: Carbon-catalyzed gasification of organic feed stocks in supercritical water. Ind. Eng. Chem. Res. 35(8), 2522-2530 (1996)

26. Savage, P.E.: A perspective on catalysis in sub- and supercritical water. J. Supercrit. Fluids. 47(3), 407-414 (2009)

27. Du, X., Zhang, R., Gan, Z., Bi, J.: Treatment of high strength coking wastewater by supercritical water oxidation. Fuel. (2010). doi:10.1016/j.fuel.2010.09.018

28. Afif, E., Azadi, P., Farnood, R.: Catalytic hydrothermal gasification of activated sludge. Appl. Catal. B. Environ. 105, 136-143 (2011)

29. Brunner, G.: Near and supercritical water. Part II: oxidative processes. J. Supercrit. Fluids. 47(3):382-390 (2009)

30. Pramanik, H., Basu, S.: Modeling and experimental validation of overpotentials of a direct ethanol fuel cell. Chem. Eng. Process. 49(7), 635-642 (2010)

31. Gaurav, D., Verma, A., Sharma, D., Basu, S.: Development direct alcohol alkaline fuel cell stack. Fuel. Cell. 10(4), 591-596 (2010)

32. Koscher, GA., Kordesch, K.: Alkaline methanol/air power devices, in: Handbook of fuel cells-fundamentals, technology and applications. In: Vielstich, W., Gasteiger, H.A., Lamm, A. (eds.), John Wiley, 4:1125-1129 (2003) 